\title{
Factors Influencing the Adaptation Decisions to Impacts of Climate Change among the Maasai Pastoral Community in Narok County, Kenya
}

\author{
Janet C. Korir ${ }^{1}$, Evans Ngenoh ${ }^{2 *}$ \\ ${ }^{1}$ Department of Geography, Moi University, Eldoret, Kenya \\ ${ }^{2}$ Department of Agricultural Economics, Humboldt University of Berlin, Berlin, Germany \\ Email: *ken.ngenoh@gmail.com
}

How to cite this paper: Korir, J.C. and Ngenoh, E. (2019) Factors Influencing the Adaptation Decisions to Impacts of Climate Change among the Maasai Pastoral Community in Narok County, Kenya. Agricultural Sciences, 10, 689-705. https://doi.org/10.4236/as.2019.105054

Received: April 2, 2019

Accepted: May 28, 2019

Published: May 31, 2019

Copyright ( 2019 by author(s) and Scientific Research Publishing Inc. This work is licensed under the Creative Commons Attribution-NonCommercial International License (CC BY-NC 4.0).

http://creativecommons.org/licenses/by-nc/4.0/

\begin{abstract}
Climate change has adverse effects on household food security and on poverty alleviation among pastoralists. This study used unique household-level data from 415 pastoral households from three sub-counties-of Narok County in Kenya to identify the major determinants of their decision to select different community-based adaptation strategies to impacts of climate change. The results from a logit model indicated that the household head characteristics (gender, education (secondary and university level), marital status, and the main occupation), socio-economic and institutional factors (access to credit, access to water, and access to climate related information) were important in enhancing the adoption of the adaptation strategies to impacts of climate change. Therefore, to enhance the resilience of pastoral communities to impacts of climate change, policies that incorporate indigenous knowledge, promote community-led adaptation, enhance effective and appropriate dissemination of climate-related information at the local level and those that provide access to relevant institutions should be formulated. In addition, livestock off-take schemes, and framework needs to be set through the establishment of effective and efficient livestock markets specifically in the pastoral areas in order to cushion pastoralist from deepening into food insecurity and poverty during the occurrences of extreme climate events.
\end{abstract}

\section{Keywords}

Adaptation Strategies, Pastoralist, Food Security, Climate Change, Maasai, Kenya

\section{Introduction}

Climate change is a global issue that poses enormous challenges described as the 
leading threat of our time by the intergovernmental panel on climate change [1]. These changes have been evident across Africa which has been drier in the last few decades with an estimated decrease of $6 \mathrm{~mm}$ /year between 1970 and 2002 [2]. Furthermore, there has been a significant increase in rainfall in South Africa and in the Volta Basin which encompasses six countries in West Africa, at the rate of $49 \mathrm{~mm} /$ year between 1901 and 1969 [2]. The same events have also been observed throughout parts of the world, with intense rains, severe and recurrent floods and droughts being reported [2] [3].

Climate change has consequences for humans that include: reduction in food production, water shortages and poor water quality and incidences of infectious diseases such as cholera, hepatitis, malaria and dengue fever which is expected to increase due to severe floods, rainfall and droughts in combination [1]. The African continent in particular, is more vulnerable and has higher risks of becoming a major global food crisis epicenter if climate change issues remain unaddressed, especially, at local levels [3]. This situation is exacerbated by other challenges such as high level of poverty, ecosystem degradation and complex disasters, which will even worsen the effects of climate change on human health and agriculture, with the crop yield being expected to decline by $10 \%-20 \%$ by 2050 if not addressed [4] [5]. This in itself will adversely contribute to poor living conditions to most of the rural communities. Furthermore, [6] has emphasized new challenges in the livestock production sector that will be posed by climate change especially among the poor resource farmers in the arid and semi-arid areas of Africa. This will be due to alteration of life cycles of disease pathogens given the much anticipated environmental changes caused by climate change.

In Kenya climate change is having far reaching negative effects on the already precarious food security situation for both crop cultivators and pastoralists [5]. The pastoral communities are specifically affected by the impacts of climate change, hence, hindering their way of life and ultimately stifling their ability to adapt to changes in their external environment [7] [8]. These impacts of climate change include: increased water scarcity caused by low rainfall and short lived water pans, increases in day time temperatures and decreases in night time temperatures, loss of pastures, and vegetation among others [8]. In Narok County for instance, climate change-related shocks/risks such as droughts and floods are becoming more frequent, more severe, and less predictable [9]. Furthermore, [10] reported a cyclic recurrence of droughts within the county, with major events experienced in 1983-84, 1991, 1993-94, 1999-2000 and 2003 periods. According to [1], the impacts of climate change on vegetation dependent livelihoods cover a wide range of possibilities including impact on health and welfare, loss of income, reduction in availability of food and loss of cultural habitat. This was evident from 1999-2000, and in 2009, when the then Narok District, lost over 500,000 animals due to prolonged drought, a situation that led to acute food shortages and rise in incidences of human-wildlife conflicts [11] [12] [13]. 
In response to this, pastoralists in this place used to sell cows and goats prior to impending droughts in the past but due to the current unpredictability of droughts and rainfall, they have had to incur great losses and reduction in the cash income derived from the sale of livestock and its products [9] [14]. This is because their capacities to cope with these climate-related shocks are lower and dynamic due to lack of economic and natural resources, poor social networks, lack of entitlements, poor marketing institutions and governance, unskilled human resources, and low uptake of modern technology [15].

The Maasai community being the occupants of this area earns their living from pastoralism and tourism both of which are threatened by the effects of climate change related shocks. Therefore, the combinations of all these effects of climate change have adversely affected the livelihoods of the Maasai community. Besides, the frequency and severity of both droughts and floods is also expected to increase in coming years, which will ultimately, lead to increased food insecurity (food shortage and poverty); loss of livelihoods; receding natural resources particularly watering points and pasture; wildlife and livestock deaths during droughts; increased human, livestock, and wildlife diseases; changes of wildlife habitats and loss of biodiversity; and human-human and human-wildlife conflicts [12] [13]. Although the extensive practice of pastoralist in Kenya suggests income as a driving factor, little past work has addressed the factors that influence the decision to adopt different community-based adaptation strategies at household-level to impacts of climate change in Narok County. Therefore, it is against this backdrop that this study sought to explore the main drivers and incentives of the adaptation strategies that are possibly being practiced in Narok County. This would be imperative in the wake of the current debate on the impacts of climate change on poor pastoralist households' livelihood situations. Furthermore, it would be valuable to the relevant stakeholders since it would complement the debate on pastoralism vis a vis climate change, and provide a basis for reformulation of strategies that are geared towards sustainable development.

\section{Conceptual Framework: Adoption of Adaptation Strategies by Pastoralists}

Adaptation strategies refer to actual adjustments, or changes in decision environments, which might ultimately enhance resilience or reduce vulnerability to observed or expected changes in climate [16]. In this study, a utility maximisation function was used in the presence of risk to conceptualize the decisions taken by pastoralists' to adopt the community-based adaptation strategies. It was assumed that the utility to these pastoralists was not defined by expected higher returns, but was derived from income stability and the implied reduction in downside risk, especially when an adaptation strategy is adopted. A risk-averse household/pastoralist maximises utility by adopting a community-based adaptation strategy that gives higher benefits than the benefits realized 
without choosing to adopt at all. In accordance with [17] and [18], the utility function was defined as follows:

$$
U_{i}=C_{i}-y \delta_{i}
$$

where $U_{i}$ is the perceived utility from the selection of a community-based adaptation strategy (i), $\quad C_{i}$ is the non-stochastic component and $\delta_{i}$ is the disturbance term indicating variation in pastoralist income. The coefficient $(y)$ captures the risk aversion of individual pastoralist, which would affect the degree of the variability in their income $\delta_{i}$. Following [19], this coefficient was defined as:

$$
\begin{aligned}
& y=-\left(\frac{\partial U / \partial \delta_{i}}{\partial U / \partial i}\right) \\
& y<0=\text { Risk Averse } \\
& =\text { if } y=0=\text { Risk Neutral } \\
& y>0=\text { Risk Loving }
\end{aligned}
$$

Pastoralist households' who are risk averse are more likely to adopt any community-based adaptation strategy, and the utility of that choice $\left(\mathrm{i}\left(U_{i}\right)\right)$ is given by the revenues generated by that strategy less the total variable costs incurred in its adoption. Therefore, given an array of adaptation strategies, a risk-averse pastoralist will choose to adopt any community-based adaptation strategy, say $\mathrm{D}$, that yields a higher expected utility than the alternatives, say $Z$, i.e.

$$
E\left(U_{D}\right)-C_{D}>E\left(U_{Z}\right)-C_{Z}
$$

where the first term is the expected utility of implementing a community-based adaptation strategy $\mathrm{D}$, and its associated costs $C_{D}$, while the second term is the expected utility of implementing a community-based adaptation strategy $\mathrm{Z}$ and its associated costs $C_{Z}$.

\section{Materials and Methods}

\subsection{Study Area and Data}

The study was carried out among pastoral community of Narok County in 2017, which is found in the Southern part of the Great Rift Valley. The County lies within latitudes $0^{\circ} 50^{\prime}$ and $2^{\circ} 05^{\prime}$ South and longitudes $35^{\circ} 58^{\prime}$ and $36^{\circ} 05^{\prime}$ East covering an approximate area of 17,944 square kilometres. It borders six counties with Nakuru to the North, Bomet, Nyamira and Kisii to the North West, Kajiado to the East and Migori to the West. The County has two types of topography; the highland towards the forest in the west that rises up an altitude of 3100 meters above the sea level and the lowland which extends up to the boundary with Tanzania in the South with an altitude of 460 meters above sea level. The average temperatures range from a minimum of $8^{\circ} \mathrm{C}$ to a maximum of $28^{\circ} \mathrm{C}$ and the County has two rainy seasons with short rains averaging $500 \mathrm{~mm}$, while long rains averaging $1800 \mathrm{~mm}$ per annum. 
The county was selected based on the fact that it is one of the arid and semi-arid areas of Kenya that has been hit by impacts of climate change, with pastoralism as the main source of livelihoods, and thus presenting the most suitable area to explore the main drivers and incentives of the decision to adopt the community-based adaptation strategies. The study was carried out in three sub-counties (Narok East, Narok South, and Narok West), with the main target being the pastoralists' household heads from the three sub-Counties. The primary data for this study was obtained through questionnaire, key informant interviews, document analysis, focus group discussions, observations and photograph taking. A multi-stage cluster sampling technique was used to select 415 pastoral households from three sub-counties through a proportionate-to-size sampling approach. In the first and the second stage, three sub-counties and two locations from each sub-county, were purposively chosen respectively, since they were the pastoral hotspots of the county based on the information from the respective sub-county agricultural offices.

Finally, pastoral household heads who had lived in this area for over 30 years within each selected locations were randomly selected because they were in a position to understand issues related to climate change over time and space. In addition, 6 key informants from Ministry of Livestock, Narok County Agricultural Sector Development Programme (ASDP), National Drought Management Authority (NDMA), County Meteorological Department, Regional Pastoral Livelihood Resilient Project (RPLRP) and Kenya National Bureau of Statistics (KNBS) office, also participated in the study. Furthermore, three focus group discussions with the community leaders from each sub-county were also carried out during the field visit. A summary of both the dependent and independent variables used in the logit model estimation are presented in Table 1. The selection of these variables was purely drawn from the literature through meta-analysis, where household, socioeconomic and institutional factors have been cited as playing a vital role in conditioning pastoralists' decisions in the context of strategies for adapting to impacts of climate change.

\subsection{The Empirical Model Specification}

The theoretical basis of this study is premised on the fact that pastoralist act to maximize both utility and profits and hence rationale in their decisions. A huge potential exists when a household adopt the appropriate community-based adaptation strategies and consequently, a pastoral household who exploit this potential will be well-off in terms of welfare gains. Therefore, the decision to cope with impacts of climate change and possibly using community-based adaptation strategies is driven by the expected higher utility and is considered under the general framework of utility or profit maximization [20] [21]. Although we cannot directly observe utility, pastoralists' actions are observed through the choices they make. For instance, we assume that $U_{j}$ and $U_{k}$ represent a household's utility choices for adopting and not adopting the adaptation strat- 
egies, which are denoted by $Y_{j}$ and $Y_{k}$ respectively. The linear random utility model could then be specified as:

$$
u_{j}=\beta_{j} X_{i}+\varepsilon_{i} \text { and } u_{k}=\beta_{k} X_{i}+\varepsilon_{k}
$$

where $U_{j}$ and $U_{k}$ are perceived utility choices for adopting and not adopting the community-based adaptation strategies $j$ and $k$, respectively, $X_{i}$ is the vector of explanatory variables that influence the perceived desirability of each choice, $\beta_{j}$ and $\beta_{k}$ are utility shifters (coefficients), and $\varepsilon$ are error terms assumed to be independently and identically distributed [22]. This framework sets the foundation for this study empirical model (Logistic regression model) for the determination of the factors that influence the adoption of the community-based adaptation strategies by pastoralists in Narok county of Kenya. The adoption of the community-based adaptation strategies to impacts of climate change in this study includes many possible responses that are used by pastoralists towards the reduction of their vulnerability to impacts of climate change by making them better able to adjust to climate change and variability, moderating potential damages, and helping them cope with adverse consequences [1]. The response variable in this case is dichotomous (binary choice variable); includes a "yes" or "no" type (those who adopted or those who did not adopt the community-based adaptation strategies) variable. The three most commonly used approaches to estimate such dummy dependent variable regression models are 1) the linear probability model (LPM), 2) the logit, and 3) the probit. The Logit and the probit models are the most frequently used models when the dependent variable happens to be dichotomous [23] [24] [25]. The logit and probit models are quite similar in most applications.

The main difference between the two is in the nature of their distribution, which is captured by Cumulative Distribution Function (CDF). Probit has a normal distribution while logit has a logistic (slightly flatter tails) distribution and therefore, the choice of probit versus logit regression depends largely on the distribution assumption one makes. Due to its comparative mathematical simplicity, many researchers have used the logit regression model in practice. [24] argues that logistic regression is powerful, convenient and flexible and is often chosen if the dependent variables are of categorical nature and/or it is not normally distributed. Some of the predictor variables in the study objectives are categorical and therefore this study will apply binary logit model to identify the factors that influence the adoption of adaptation strategies to ICC amongst pastoralists in Narok County. Following the recommendation of [25], the cumulative logistic probability model is econometrically specified as:

$$
P_{i}=F\left(Z_{i}\right)=F\left(\alpha+\sum_{i=1}^{n} \beta_{i} X_{i}\right)=\frac{1}{1+\mathrm{e}^{-z_{i}}}
$$

where, $P_{i}$ is the probability that pastoralists used at least one adaptation strategy given $X_{i}$.

$X_{i}$ represents the $\mathrm{i}^{\text {th }}$ explanatory variables; 
e denotes the base of natural logarithms, which is approximately equal to 2.718;

$\alpha$ and $\beta_{i}$ are parameters to be estimated.

Central to the use of logistic regression is the logit transformation of $p$ given by $Z$. that is, to get linearity, we take the natural logarithms of odds ratio Equation (1), which results in the logit model as given by:

$$
Z_{i}=\ln \left(\frac{P_{i}}{1-P_{i}}\right)=\alpha+\beta_{1} X_{1}+\beta_{2} X_{2}+\cdots+\beta_{n} X_{n}+\varepsilon
$$

where $Z_{i}$ is the indicator of pastoralists' household that adopted the community-based adaptation strategies or not, $P$ is the probability of the event's occurrence, $X_{i}$ is a vector of household socio-economic, demographic, institutional, and communication characteristics (Table 1). $\alpha$ is a constant, $\beta_{i}$ are corresponding vectors of regression and $\varepsilon$ is disturbance term. The variables that were considered are age, education level, marital status, gender, main occupation, and access to capital, information, labour, water and other infrastructural services (roads, health among others) by the pastoralist.

\section{Results and Discussion}

\subsection{Descriptive Statistics}

The respondents were asked questions about whether they witnessed changes in climate ever since they reside in the area. Furthermore, those pastoralists who had witnessed changes in climate were subsequently asked if they had faced some impacts from the changes and further, if they had responded to them by adopting community-based adaptation strategies that would counteract the

Table 1. Description of variables included in the Logit Model.

$X_{2} \quad$ Age of the household head ( $1=$ Less than 20 Years, $2=20-40$ Years, $3=40-60$ Years, $4=$ Above 60 years). +

$X_{3} \quad$ Marital status of household age, $(1=$ Single, $2=$ Married, $3=$ Divorced $/$ separated $)$.

$X_{4} \quad$ Education level of a household head $(1=$ None, $2=$ primary, $3=$ secondary, $4=$ tertiary, $5=$ university, and $6=$ adult education)

$X_{5} \quad$ Main occupation of the Household head, ( $1=$ Civil servant, $2=$ Self-employed, $3=$ Farmer, $4=$ Pastoralism, 5 = Casual labour, $6=$ Conservancy employee)

$X_{6} \quad$ Access to capital, $(0=$ No, $1=$ Yes $)$

$X_{7} \quad$ Access to necessary information, $(0=$ No, $1=$ Yes $)$

$X_{8} \quad$ Access to Water, $(0=$ No, $1=$ Yes $)$

$X_{9} \quad$ Access to Infrastructural services, $(0=$ No, $1=$ Yes $)$

Source: Author's compilation. 
associated negative impacts. It was observed that $63.4 \%$ (264) of the surveyed pastoralist households had witnessed changes in climate in the area, while $94 \%$ (391) of them had managed to adopt various community-based adaptation strategies at household-level. Accordingly, it was observed that, pastoralist from Narok County, had selected various community-based adaptation strategies, with 29\% (121) having adopted crop cultivation, and livestock diversification, while 12\% (50) had constructed water harvesting schemes. In addition, 10\% (42) had chosen to migrate to other places for pastures and water, while $9 \%$ (38) indicated that they had implemented soil conservation and land paddocking as adaptation strategies to impacts of climate change. A further 2\% (9) of the pastoralists had cultivated artificial pastures and reduced the number of livestock while 1\% (5) had invested in irrigation facilities. These community-based adaptation strategies adopted by Maasai pastoralists in Narok county were similar to other findings in the literature on impacts of climate change and adaptation strategies [26] [27] [28]. Moreover, the study results (Table 2) indicated that the majority $(86 \%, 357)$ of the pastoralist were married.

They were predominantly male $(84 \%, 349)$, with an average age of between 30 - 40 years, and $66 \%$ (248) of them had no education at all. The level of access to capital and information was $28 \%(117)$, with the majority $(99 \%, 411)$ having no access to labour. The results further showed that pastoralist had limited access to critical services, reflected in their level of access to basic infrastructural services $(4 \%, 17)$, and water $(26 \%, 108)$. Finally, the results indicated that pastoralist had limited livelihood options, as indicated by their household heads main occupation being self-employed $(16 \%, 67)$, farmers $(8 \%, 34)$, civil servant or salaried $(1 \%, 5)$, and casual labourers $(2 \%, 9)$.

\subsection{Determinants of the Decision to Adapt to Impacts of Climate Change-Related Risks}

The study finally sought to determine the main factors that were responsible for the decision to adopt the community-based adaptation strategies by the pastoral households in Narok County. This objective was achieved through the use of a logistic regression model and the results are presented in Table 3 . The results from the logit regressions (marginal effects) showed that several factors influence the decision to adopt or not to adopt the community-based adaptation strategies by the pastoral community. These included; education (secondary level), occupation (civil servant/salaried and farmer), marital status, gender, access to capital, water, and information of the pastoralists.

The marginal effect of the secondary education level was significant correlated with positive effects on the adoption of the adaptation strategies among the pastoralist. This implied that an advancement in the level of education up to secondary school level would positively influence the adoption of community-based adaptation strategies. However, attainment of university level of education indicated significant negative effects on the adoption of appropriate community-based 
Table 2. Description of variables used in the Logit model.

\begin{tabular}{|c|c|c|c|}
\hline Dependent variables & Description of the variables & Mean & Std. Dev. \\
\hline Adaptation & Dummy $=1$ if a household had selected community-based adaptation strategies, 0 otherwise & 0.60 & 0.482 \\
\hline \multicolumn{4}{|l|}{ Independent variables } \\
\hline Gender $(0,1)$ & Dummy $=1$ if the gender of the household head is male, 0 otherwise & 0.16 & 0.364 \\
\hline Marital status & Household head marital status & & \\
\hline Single & Household heads who are single & 0.13 & 0.331 \\
\hline Married & Household heads who are married & 0.86 & 0.396 \\
\hline Divorced/Separated & Household heads who are either divorced or separated & 0.01 & 0.109 \\
\hline Age & Household head age in years & & \\
\hline Less than 20 Years & Household head with less than 20 years & 0.04 & 0.371 \\
\hline Between 20 - 30 Years & Household head with between 20 - 30 years & 0.24 & 0.428 \\
\hline Between 30 - 40 Years & Household head with between 30 - 40 years & 0.40 & 0.489 \\
\hline Above 40 Years & Household head with above 40 years & 0.32 & 0.468 \\
\hline Education level & Household head level of education & & \\
\hline No education & Household heads with no education at all & 0.66 & 0.473 \\
\hline Primary & Household heads with primary school level of education & 0.13 & 0.337 \\
\hline Secondary & Household heads with secondary school level of education & 0.14 & 0.348 \\
\hline Tertiary & Household heads with tertiary school level of education & 0.03 & 0.174 \\
\hline University & Household heads with university school level of education & 0.02 & 0.154 \\
\hline Main occupation & Household head main occupation & & \\
\hline Pastoralist & Household head whose main occupation is pastoralism & 0.71 & 0.453 \\
\hline Self-employed & Household head whose main occupation is self-employment & 0.16 & 0.368 \\
\hline Farmer & Household head whose main occupation is farming & 0.08 & 0.278 \\
\hline Civil servant (Salaried) & Household head whose main occupation is salaried employment & 0.01 & 0.059 \\
\hline Casual labourer & Household head whose main occupation is casual labourer & 0.02 & 0.207 \\
\hline \multicolumn{4}{|l|}{ Other parameters } \\
\hline Access to capital $(0,1)$ & Dummy $=1$ if household had access to capital, 0 otherwise & 0.28 & 0.449 \\
\hline Access to information $(0,1)$ & Dummy $=1$ if household had access to information, 0 otherwise & 0.28 & 0.452 \\
\hline Access to labour $(0,1)$ & Dummy $=1$ if household had access to labour, 0 otherwise & 0.01 & 0.085 \\
\hline Access to water $(0,1)$ & Dummy $=1$ if household had access to water, 0 otherwise & 0.26 & 0.437 \\
\hline Access to infrastructure $(0,1)$ & Dummy $=1$ if household had access to basic infrastructural services, 0 otherwise & 0.04 & 0.187 \\
\hline
\end{tabular}

adaptation strategies to impacts of climate change from the results. This also implied that the level of education of a pastoralist had an influence on the decision to adapt, in that the higher the education level of pastoralist is, the lower the adoption of community-based adaptation strategies against the impacts of climate change and vice versa. This could be attributed to the fact that as the level of education was advancing, people would tend to shift their focus from pastoralism to 
Table 3. Determinants of pastoralists' decision to adopt community-based adaptation strategies.

\begin{tabular}{|c|c|c|c|c|}
\hline$\underline{\text { Determinant factors/Variables }}$ & $\underline{\text { Parameters }}$ & $\underline{\text { Marginal effects }}$ & $\underline{\text { Standard error }}$ & $\underline{P \text {-value }}$ \\
\hline Gender $(0,1)$ & $X_{1}$ & 0.5046 & 0.2901 & $0.082^{*}$ \\
\hline \multicolumn{5}{|l|}{ Marital status } \\
\hline Married & $X_{2}$ & 0.2264 & 0.1059 & $0.022^{* *}$ \\
\hline Divorced/Separated & $X_{3}$ & 0.2001 & 1.0773 & 0.853 \\
\hline \multicolumn{5}{|l|}{ Age } \\
\hline Between 20 - 30 Years & $X_{4}$ & -0.0967 & 0.5965 & 0.871 \\
\hline Between 30 - 40 Years & $X_{5}$ & -0.2062 & 0.6575 & 0.754 \\
\hline Above 40 Years & $X_{6}$ & -0.0504 & 0.6694 & 0.940 \\
\hline \multicolumn{5}{|l|}{ Education level } \\
\hline Primary & $X_{7}$ & 0.2486 & 0.3419 & 0.467 \\
\hline Secondary & $X_{8}$ & 0.4866 & 0.1786 & $0.009^{* * *}$ \\
\hline Tertiary & $X_{9}$ & 0.5479 & 0.7204 & 0.447 \\
\hline University & $X_{10}$ & -0.1035 & 0.0328 & $0.088^{*}$ \\
\hline \multicolumn{5}{|l|}{ Main occupation } \\
\hline Self-employed & $X_{11}$ & -0.3822 & 0.3246 & 0.239 \\
\hline Farmer & $X_{12}$ & 0.3995 & 0.1704 & $0.018^{* *}$ \\
\hline Civil servant (Salaried) & $X_{13}$ & 0.2529 & 0.1104 & $0.013^{* *}$ \\
\hline Casual labourer & $X_{14}$ & -2.0231 & 0.8431 & $0.016^{* *}$ \\
\hline Access to capital $(0,1)$ & $X_{15}$ & 0.7384 & 0.2792 & $0.008^{* * *}$ \\
\hline Access to Information $(0,1)$ & $X_{16}$ & 0.4307 & 0.2026 & $0.007^{* * *}$ \\
\hline Access to Labour $(0,1)$ & $X_{17}$ & -0.9976 & 1.2486 & 0.424 \\
\hline Access to water $(0,1)$ & $X_{18}$ & 0.3193 & 0.1451 & $0.030^{* *}$ \\
\hline Access to infrastructural services $(0,1)$ & $X_{19}$ & 0.5219 & 0.6242 & 0.403 \\
\hline \multicolumn{5}{|l|}{ Diagnostic statistics } \\
\hline Log likelihood & -257.57003 & & & \\
\hline $\operatorname{LR} \operatorname{chi}^{2}(19)$ & 25.17 & & & \\
\hline Number of observations & 415 & & & \\
\hline Prob $>$ chi2 & 0.0000 & & & \\
\hline
\end{tabular}

${ }^{* * *}(\mathrm{p}<0.01),{ }^{* *}(\mathrm{p}<0.05),{ }^{*}(\mathrm{p}<0.10)$. Source: Survey Data $(2017)$.

other livelihood options such as seeking employments in bigger towns and/or cities and therefore they were less likely to participate in pastoralism as a means of livelihood.

The findings were similar to those documented by [29] who reported that higher level of education had negative relationship with the adoption of terracing and inorganic fertilizer as adaptation strategies to impacts of climate change 
in Uganda. In addition, [30] also found out that higher level of education was inversely related to adoption of some adaptation strategies to impacts of climate change in Forte-Jacques. On the contrary, [31] indicated that, farmers with higher levels of education were more likely to use improved technologies in order to adapt to impacts of climate change.

Furthermore, occupation of the household heads who were civil servantsor in salaried employment significantly had positive influence on the uptake of the community-based adaptation strategies among the pastoralist. This implied that household heads with off-farm employment were more likely to adopt the community-based adaptation strategies to impacts of climate change because they could be more stable financially to be able to adapt. Similarly, pastoral household heads working as casual labourers were having significant but negative effects on the adoption of the community-based adaptation strategies. This could be attributed to the fact that casual workers were not always available especially during the period of extreme weather conditions when the demand for cash is at its peak and hence the inverse relationship. The results were in agreement with the sentiments of a focus group discussant who reported that some of the pastoralists engaged in the conservancies as casual labourers were enjoying the marginal benefits of being there by allowing their livestock to graze in the conservancies during the long dry spell hence did not feel the problems faced by their counterparts outside the conservancies. The results were also in agreement with those of [32] [27] and [33] who noted that farmers who had other income options could afford the cost of irrigation which was an ex-ante strategy, and could use less of the agronomic practices such as soil conservation and the use of different crop varieties which were ex-post adaptation strategies.

On the other hand, the household heads whose occupation was pastoralism had positive and significant influence on the decision to adopt the community-based adaptation strategies to impacts of climate change. This results indicated that households with pastoralism as their main occupation had the highest probability of adopting the community-based adaptation strategies to impacts of climate change because they focused all their resources and energy towards improving their livelihood which was their only source of income [32] [34] [14]. These findings therefore illustrated that the decision to adapt to impacts of climate change is strongly dependent on the characteristics of the pastoralists themselves and therefore, the policy intervention that seeks to enhance these characteristics will have significant impact on adaptation. [27], earlier on pointed out that when local people play a role, there is a sense of ownership and they feel empowered. Furthermore according to [28] and [14] community-based tool in adaptation process is the best tool, since it seeks to facilitate the local adaptation capacities of the community at the same time promotes initiative and creativity of the people.

The results further illustrated that the married household heads had statistically significant and positive influence on the adoption of the communi- 
ty-based adaptation strategies towards mitigating the negative effects of impacts of climate change. This was supported by the fact that, marriage is a basic unit of an institution which is a conduit to the access and use of the productive resources especially in the study area where cultural practices are strictly followed and adhered to. In addition, some of the productive assets for example land and other inherited assets, especially in the African context, are not transferred to an individual who is not married [14].

Gender of the household head was found out from the results to be statistically significant with positive effects on the adoption of the community-based adaptation strategies to impacts of climate change among the pastoral community. This implied that male-headed households among the pastoral community were more likely to adopt the adaptation strategies to impacts of climate change. This was attributed to the fact that men in the African culture are regarded as the owners of productive resources [34] and hence can be flexible in carrying out any adjustments in these assets/resources including using them as collateral in financial institutions to acquire credit facilities. In other words, men are more able to diversify income sources and adapt to climate change because they are in control of household financial resources. These findings were confirmed by the results of previous studies which revealed that in Sub-Saharan Africa (SSA), female household heads have lower levels of education, less access to markets and credit and other inputs and hence less likely to meet the community-level investment demands of climate change adaptation strategies [35]. In addition, [36] found out that male headed households had a positive relationship with adoption of climate smart technologies in Kenya, which are regarded as the best adaptation to impact of climate change. Moreover, gender had been reported to be having positive relationship with the adoption of irrigation [37], and fallow and terracing [29], as African farmers' strategies for adapting to climate change in Ethiopia and Uganda respectively.

The study results further showed that access to socio-economic and institutional services such as capital, water, and information were significant with positive effects on the decision to adopt the community-based adaptation strategies that are taken by the pastoralist households. This implied that household who had access to these services and resources were more likely to adopt appropriate community-based adaptation strategies to counteract the negative effects from the impacts of climate change. This was because access to water and capital for example would enable the pastoral households to meet the cost of adaptation strategies that were costly like irrigation which is the best strategy against dry spell/drought events. The study result was consistent with previous findings that indicated that access to credit was an important variable which commonly had a positive effect on the adoption of the community-based adaptation strategies to impacts of climate change [31] [38]. On the other hand, information access was a necessary and sufficient factor that aids in the adoption of the community-based adaptation strategies to impacts of climate change since it disseminates 
the required skills and knowledge that can be used in the adoption of best adaptation strategies. This is because an individual who has access to climate information is more likely to take an immediate action towards the adoption of strategies to combat the impact from risks related to climate change. Several studies have reported a strong positive relationship between access to information and the adoption of the adaptation strategies to impacts of climate change [32] [39] [40] [41]. Similar sentiments were argued by [16] and [40], who asserted that farmers were more willing to make more significant changes to their farming practices but they were unable to do so due to constraints, including lack of money needed for the investment, lack of resources (water or land), lack of inputs and lack of information.

\section{Conclusions}

The study sought to determine the factors that affect the decision to adopt the community-based adaptation strategies among the Maasai pastoralist in Kenya using a logit model. The model results from the marginal analysis indicated that household heads' characteristics such as gender, education (secondary and university level), marital status, and the main occupation (farmer, casual labourer, and civil servant/salaried), had significant effect on the choice of adaptation strategies to impacts of climate change. The study further revealed that socio-economic and institutional factors such as access to credit, access to water, and access to climate related information were important in enhancing the adoption of the adaptation strategies to impacts of climate change.

These results are of policy implication where there is a need for the integration of indigenous knowledge system that can lead to effective adoption of adaptation strategies towards safeguarding pastoral livelihoods. At the same time there is a need for clear policies on how climate information can be effectively and appropriately disseminated at the local level so as to reach every part of pastoral areas and to keep them abreast of climatic changes and be in a position to salvage their livelihoods on time. Therefore, the government (of Kenya) in collaboration with agricultural sector stakeholders, and mobile service providers should assist the pastoralists in ensuring the development of efficient and effective mobile phone-based agricultural information access systems that will relay the required information in real time. These will also promote access to other services such as mobile banking and credit markets/services that can be channelled through such systems, hence easing the credit challenges faced by pastoralist, especially in remote rural areas where formal financial services are limited. Moreover, critical information, for instance, those that clearly indicate the adaptation strategies that work together (compliments), and that do not substitutes should be designed and incorporated in such systems. Market information like the knowledge and prices for livestock can also be incorporated in these systems for ease of accessibility by pastoralist and other actors along the livestock value chains especially during prolonged drought periods. 
Accordingly, policies that are aimed at promoting community-led adaptation strategies and especially among the pastoralists are of critical importance, since it will enhance more viable measures by the affected community. This is necessary since the decision to adapt is strongly dependent on the characteristics of the pastoralists' households and thus policy intervention that seeks to enhance these characteristics will have impact on adaptation. Furthermore, it is imperative to promote policies that seek to establish the institutions that provide ease of access to basic services such as water, education, and health by the pastoralists. These include; investment in large scale irrigation schemes, and water pans by the government along the pastoral strip that can buffer pastoralist from dependence on food aid or engage in human-wildlife conflicts during extreme events. It will also induce them to practice mixed farming which in turn is an adaptation strategy in itself. Finally, the creation of affordable credit schemes and establishment of appropriate water harvesting and usage technologies in pastoral areas will have a positive and direct effect on the adoption of the adaptation strategies to impacts of climate change.

Therefore, in order to assist the pastoralists to improve their livelihoods by effectively adopting appropriate community-based adaptation strategies, the government should partner with financial institutions to ensure that they get access to affordable credit services. These will enable them to get access to the necessary facilities for smooth pastoralism operation and thus secure strong adaptive capacity to climate change. The credit services could also be channeled through the mobile phone-based systems and pastoralist organizations because it will empower them as well as help reduce transaction costs and the chances of default among pastoralists. Based on the scope of this study, it is recommended that similar study should be done in other pastoral counties of the country for comparison purposes and to allow for generalization of the findings. Further, studies should be done to determine why pastoralists are choosing different community-based adaptation strategies to impacts of climate change.

\section{Acknowledgements}

The authors are very grateful to the National Commission for Science, Technology and Innovation (NACOSTI) for funding the study. We also thank the team who played a role in the study design, survey, data entry and analysis for their efforts. We would also like to appreciate the team who played a role from the project design, survey, data entry, and analysis for their efforts. The opinions conveyed herein are exclusively those of the authors and not of the affiliated institutions.

\section{Conflicts of Interest}

The authors declare no conflicts of interest regarding the publication of this paper.

\section{References}

[1] IPCC (2007) Climate Change 2007. Mitigation, Contribution of Working Group III 
to the Fourth Assessment Report of the Intergovernmental Panel on Climate Change.

[2] Oguntunde, P.G., Friesen, J., van de Giesen, N. and Savenije, H.H.G. (2006) Hydro-Climatology of the Volta River Basin in West Africa; Trends and Variability from 1901 to 2002. Physics and Chemistry of the Earth, 31, 1180-1188.

[3] Bunce, M., Rosendo, S. and Brown, K. (2010) Perceptions of Climate Change, Multiple Stressors and Livelihoods on Marginal African Coasts. Environment, Development and Sustainability, 12, 407-440. https://doi.org/10.1007/s10668-009-9203-6

[4] Thornton, P.K. and Jones, P.G. (2008) Unpublished Data Layers. ILRI, Nairobi.

[5] Mwebeza, R. and Kotzé, L.J. (2009) Environmental Governance and Climate Change in Africa: Legal Perspectives. ISS Monograph Series 167, Pretoria, 308 p.

[6] Olwoch, J.M., Reyers, B., Engelbrecht, F.A. and Erasmus, B.F.N. (2008) Climate Change and the Tick-Borne Disease, Theileriosis (East Coast Fever) in Sub-Saharan Africa. Journal of Arid Environments, 72, 108-120. https://doi.org/10.1016/j.jaridenv.2007.04.003

[7] Ogindo, H.O., Otieno, A.W., et al. (2009) An Assessment of Drought Induced Vulnerability of the Turkana Pastoralist Community Livelihoods in Northern Kenya and Its Ability to Cope with Climate Change. Climate Change Adaptation in Africa Program 2009-10 Annual Report.

[8] Jane, K.N., Mwangi, J.G. and Nkurumwa, A.O. (2013) Climate Change Challenges and Adaptation Strategies among the Pastoralits of Laikipia County Kenya. International Journal of Agricultural Extension, 1, 20-30.

[9] Nabutola, W. (2010) The Mau Forest in the Rift Valley: Kenya's Largest Water Tower. A Perfect Model for the Challenges and Opportunities of a Sustainable Development Project? FIG Congress 2010: Facing the Challenges-Building the Capacity, Sydney, 11-16 April 2010, 1-24.

[10] FAO (2010) FAO Strategy for Forests and Forestry. Rome. http://www.fao.org/docrep/012/al043e/al043e00.pdf

[11] Nkurumwa, A.O., Mwangi, J.G. and Kathuri, N.J. (2010) Livelihood Diversification and Enhanced Food Security through Agro-Pastoralism: Socio-Cultural and Other Challenges among Maasai Pastoralists of Narok North District of Kenya. 2nd Ruforum Biennial Meeting, Entebbe, 20-24 September 2010, 20-24.

[12] Gicheru, P., Makokha, S.N., Le, C., Gachimbi, L.N., Wamuongo, J.W., McNeil, D. and Brouwer, F. (2012) Land Subdivision and Degradation in Narok, Kenya. In: McNeill, D., Nesheim, I. and Brouwer, F., Eds., Land Use Policies for Sustainable Development. Exploring Integrated Assessment Approaches, Edward Elgar Publishing, Cheltenham, 148. https://doi.org/10.4337/9781781002476.00016

[13] Nesheim, I., Reidsma, P., Bezlepkina, I., Verburg, R., Abdeladhim, M.A., Bursztyn, M., Chen, L., Cisse, Y., Feng, S., Gicheru, P., Konig, J.H., Novira, N., Purushothaman, S., Rodrigues-Filho, S. and Sghaier, M. (2014) Causal Chains, Policy Trade-Offs and Sustainability: Analysing Land (mis) Use in Seven Countries in the South. Land Use Policy, 37, 60-70. https://doi.org/10.1016/j.landusepol.2012.04.024

[14] Opiyo, F., Wasonga, O.V., Nyangito, M.M., Mureithi, S.M., Obando, J. and Munang, R. (2016) Determinants of Perceptions of Climate Change and Adaptation among Turkana Pastoralists in North-Western Kenya. Climate and Development, 8 , 179-189. https://doi.org/10.1080/17565529.2015.1034231

[15] Okoti, M., Kungu, J. and Obando, J. (2014) Impact of Climate Variability on Pastoral Households and Adaptation Strategies in Garissa County, Northern Kenya. 
Journal of Human Ecology, 45, 243-249.

https://doi.org/10.1080/09709274.2014.11906697

[16] Cooper, P.J.M., Stern, R.D., Noguer, M. and Gathenya, J.M. (2013) Climate Change Adaptation Strategies in Sub-Saharan Africa: Foundations for the Future. InTech Open, London, 327-356.

[17] Norton, R.D. and Hazell, P.B. (1986) Mathematical Programming for Economic Analysis in Agriculture. Collier Macmillan, London.

[18] Greene, W.H. (2003) Econometric Analysis. 5th Edition, Prentice Hall, Upper Saddle River.

[19] Finger, R. and Schmid, S. (2008) Modeling Agricultural Production Risk and the Adaptation to Climate Change. Agricultural Finance Review, 68, 25-41. https://doi.org/10.1108/00214660880001217

[20] Pryanishnikov, I. and Zigova, K. (2003) Multinomial Logit Models for the Australian Labour Market. Australian Journal of Statistics, 32, 267-282. https://doi.org/10.17713/ajs.v32i4.461

[21] Norris, P.E. and Batie, S.S. (1987) Virginia Farmers' Soil Conservation Decisions: An Application of Tobit Analysis. Southern Journal of Agricultural Economics, 19 , 79-90. https://doi.org/10.1017/S0081305200017404

[22] Greene, W.H. (2000) Econometric Analysis (International Edition). Prentice-Hall International, London.

[23] Wooldridge, J.M. (2010) Econometric Analysis of Cross Section and Panel Data. MIT Press, Cambridge.

[24] Gujarati, D. (2004) Basic Econometrics. United States Military Academy, West Point.

[25] Brooks, C. (2008) Introductory Econometrics for Finance. Cambridge University, Cambridge. https://doi.org/10.1017/CBO9780511841644

[26] Bryan, E., Ringler, C., Okoba, B., Roncoli, C., Silvestri, S. and Herrero, M. (2011) Coping with Climate Variability and Adapting to Climate Change in Kenya: Household and Community Strategies and Determinants. Report to the World Bank Report.

[27] McCord, P.F., Cox, M., Schmitt-Harsh, M. and Evans, T. (2015) Crop Diversification as a Smallholder Livelihood Strategy within Semi-Arid Agricultural Systems near Mount Kenya. Land Use Policy, 42, 738-750. https://doi.org/10.1016/j.landusepol.2014.10.012

[28] Mulwa, C., Marenya, P., Rahut, D.B. and Kassie, M. (2017) Response to Climate Risks among Smallholder Farmers in Malawi: A Multivariate Probit Assessment of the Role of Information, Household Demographics, and Farm Characteristics. Climate Risk Management, 16, 208-221. https://doi.org/10.1016/j.crm.2017.01.002

[29] Birungi, P. and Hassan, R. (2010) Poverty, Property Rights and Land Management in Uganda. African Journal of Agricultural and Resource Economics, 4, 48-69.

[30] Bayard, B., Jolly, C.M. and Shannon, D.A. (2006) The Adoption and Management of Soil Conservation Practices in Haiti: The Case of Rock Walls. Agricultural Economics Review, 7, 28.

[31] Ndamani, F. and Watanabe, T. (2015) Farmers' Perceptions about Adaptation Practices to Climate Change and Barriers to Adaptation: A Micro-Level Study in Ghana. Water, 7, 4593-4604. https://doi.org/10.3390/w7094593

[32] Deressa, T.T., Hassan, R.M., Ringler, C., Alemu, T. and Yesuf, M. (2009) Determi- 
nants of Farmers' Choice of Adaptation Methods to Climate Change in the Nile Basin of Ethiopia. Global Environmental Change, 19, 248-255.

https://doi.org/10.1016/j.gloenvcha.2009.01.002

[33] Mugi-Ngenga, E.W., Mucheru-Muna, M.W., Mugwe, J.N., Ngetich, F.K., Mairura, F.S. and Mugendi, D.N. (2016) Household's Socio-Economic Factors Influencing the Level of Adaptation to Climate Variability in the Dry Zones of Eastern Kenya. Journal of Rural Studies, 43, 49-60. https://doi.org/10.1016/j.jrurstud.2015.11.004

[34] Shongwe, P., Masuku, M.B. and Manyatsi, A.M. (2014) Factors Influencing the Choice of Climate Change Adaptation Strategies by Households: A Case of Mpolonjeni Area Development Programme (ADP) in Swaziland. Journal of Agricultural Studies, 2, 86-98. https://doi.org/10.5296/jas.v2i1.4890

[35] Blackden, C.M. and Wodon, Q. (2006) Gender, Time Use, and Poverty in Sub-Saharan Africa. Vol. 73, World Bank Publications, Washington DC.

https://doi.org/10.1037/e602512012-001

[36] Ogada, M.J., Nyangena, W. and Yesuf, M. (2010) Production Risk and Farm Technology Adoption in the Rain-Fed, Semi-Arid Lands of Kenya. African Journal of Agricultural and Resource Economics, 4, 154-174.

[37] Deressa, T.T., Hassan, R.M. and Ringler, C. (2011) Perception of Adaptation to Climate Change by Farmers in the Nile Basin of Ethiopia. The Journal of Agricultural Science, 149, 23. https://doi.org/10.1017/S0021859610000687

[38] Fosu-Mensah, B.Y., Vlek, P.L. and MacCarthy, D.S. (2012) Farmers' Perception and Adaptation to Climate Change: A Case Study of Sekyedumase District in Ghana. Environment, Development and Sustainability, 14, 495-505. https://doi.org/10.1007/s10668-012-9339-7

[39] Bryan, E., Deressa, T.T., Gbetibouo, G.A. and Ringler, C. (2009) Adaptation to Climate Change in Ethiopia and South Africa: Options and Constraints. Environmental Science and Policy, 12, 413-426. https://doi.org/10.1016/j.envsci.2008.11.002

[40] Bryan, E., Ringler, C., Okoba, B., Roncoli, C., Silvestri, S. and Herrero, M. (2013) Adapting Agriculture to Climate Change in Kenya: Household Strategies and Determinants. Journal of Environmental Management, 114, 26-35. https://doi.org/10.1016/j.jenvman.2012.10.036

[41] Feleke, F.B., Berhe, M., Gebru, G. and Hoag, D. (2016) Determinants of Adaptation Choices to Climate Change by Sheep and Goat Farmers in Northern Ethiopia: The Case of Southern and Central Tigray, Ethiopia. SpringerPlus, 5, 1692.

https://doi.org/10.1186/s40064-016-3042-3 